\title{
Teaching Robotics to Students in Pandemic Conditions
}

\author{
N. S. Kolyeva ${ }^{1, *}$, O. L. Kopnova², E. V. Klimov², V.V. Serebrenikova² \\ ${ }^{1}$ Ural State University of Economics, Ekaterinburg, Russia \\ ${ }^{2}$ North Kazakhstan State University. M Kozybaeva, Petropavlovsk, Kazakhstan \\ ${ }^{*}$ Corresponding author. Email nkoleva@mail.ru
}

\begin{abstract}
The introduction of quarantine measures seriously changes the approach to teaching technical disciplines, which include robotics. If in the traditional learning mode, students in the classroom have experience in collecting robotic designers, then in the quarantine mode they are deprived of this opportunity. This problem is aggravated by the fact that upon completion of the course, students of the pedagogical specialty come to school with no experience of working with real robotic constructors. Given that this discipline is included in the curriculum of students most often in senior years, it is not always possible to postpone it to a later date. In this article, the authors propose a methodology for organizing the educational activities of students of pedagogical specialties in the field of computer science, taking into account distance learning during the quarantine period. The methodology proposed by the authors was tested under the conditions of the introduction of quarantine measures and showed high results on the exam.
\end{abstract}

Keywords: robotics, Arduino programming, 3D models creation, project activities.

\section{INTRODUCTION}

The main resource for the development of socioeconomic capital is education and science. Consequently, the goal of higher education is to form a specialist personality that has the qualities of a creative personality, ready to continuously improve their knowledge in accordance with the requirements of the surrounding reality. In the Messages of the First President N.A. Nazarbayev to the people of Kazakhstan, the technological modernization of the economy is called the first priority: "... We must cultivate new industries that are created using digital technologies. This is an important complex task. ...An important condition for the formation of new industries is the support of innovations and their rapid introduction into production.." [1]. Robotics is one of the promising areas of economic development and therefore many advanced countries are interested in the development of this area of science. According to many foreign colleagues, robotics training should begin at school age and continue at the university [2-4]. The trends in the development of robotics oblige to introduce a separate discipline into the course of computer science teachers, allowing them to take a comprehensive look at the processes of development of this branch of science on the one hand, and on the other hand to develop a methodology for teaching robotics starting from the primary school level.

In the case of full-time training before the pandemic, students study robotic LEGO, Fischertechnik, organize team competitions with the participation of robots. However, the introduction of quarantine measures made it impossible to conduct classes using robotic constructors, which led to a restructuring of the approach to teaching the discipline "Robotics". The article proposes a methodology for conducting robotics classes in online learning, tested by the authors during the first semester of the 2020-2021 academic year.

\section{MATERIALS AND METHODS}

Robotics training can be divided into three main areas (Figure 1):

Practical direction (PD): acquisition of skills in designing robotic devices, which involves students mastering skills such as designing and assembling a circuit of a robotic device in the online modeling system Tinkercad. Tinkercad also allows you to debug the program for the Arduino microcontroller online. It is advisable to form the skill of reducing the number of wires and, as a consequence, the design of the final product itself in the online tool for designing chips and printed circuit boards EasyEDA. For the convenience of 


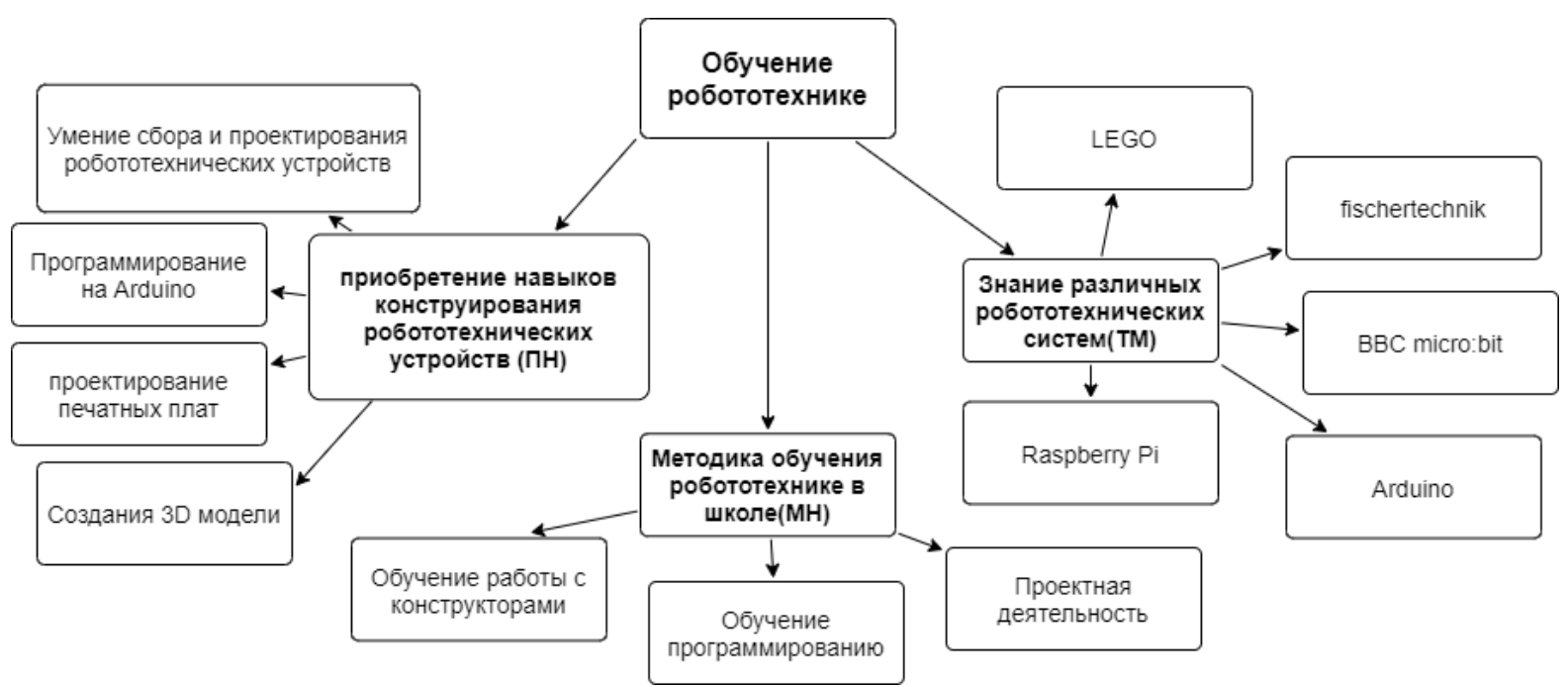

Figure 1 The main directions of teaching robotics to students of Computer Science specialties, where:

Обучение робототехнике - Robotics training; Приобретение навыка конструирования робототехнических устройств - Creating robotic devices skill; Умение сбора и проектирования робототехнических устройств Assembling and designing robotic devices skill; Программирование на Ardino - Ardino Programming; Проектирование печатных плат - Printed circuit boards design; Создание 3D модели - 3D model creation; Методика обучения робототехнике в школе - Methodology for teaching robotics at school; Обучение работе с конструкторами - Training to work with constructors; Обучение программированию Programming training; Проектная деятельность - Project activities; Знание различных робототехнических систем (ТM) - Knowledge of various robotic systems (TM).

fastening and providing external protection of structures, students also need 3D design knowledge, which can also be mastered in the Tinkercad environment.

Theoretical material (TM): knowledge of various robotic systems will allow students of the computer science specialty to fully represent the market of robotic designers and systems, to build their methodological lines of teaching within the framework of circle and project activities. In our opinion, it is advisable to use video reviews for a more complete understanding during lectures and independent work of students.

Methodological direction (MD): methods of teaching robotics at school. Within the framework of this direction, each teacher develops his own methodological line and, as practice shows, students in the first years of their pedagogical activity often copy the teachers who are most authoritative for themselves. That is why it is very important to pay maximum attention to the methodology of conducting classes while learning didactic specialties. Since in the pandemic, students are limited in direct communication with the teacher and the mental transfer of methodological experience, well-chosen videos on the discipline can also come to the rescue. The video review will give a complete picture of the principles of operation of robotic devices, allow you to better navigate the material, and also see several methodological approaches to teaching this subject.
However, not all YouTube channels can provide quality content on this topic. We believe that it is necessary to comply with the following requirements for the selection of video clips for a lecture. Lack of emotions in the video (the author of the video should not impose his opinions and emotions on the audience, since everyone can have their own opinion on technologies and methods of their application in a project or life).

It is advisable to give preference to video materials filmed as part of educational programs or courses. The video should contain brief, concise information on the topic, a description of the design solutions of robotic devices, demonstration of the stages of assembly and operation of the robot or a detailed description of the principles of its operation. If the video contains a program code, it is desirable that it be clearly displayed on the screen or for students to copy and check its functionality.

The duration of a video or several videos is no more than 30 minutes, so that there is time to discuss the watched video with the students.

\section{Distribution of course hours}

The course consists of a theoretical and practical part. As part of the lectures (the theoretical part of the course), we consider various robotic systems and constructors with students, analyze the presented material, and also discuss the methodology for presenting this information to students. 
Table 1. Planning of the lecture part of the course.

\begin{tabular}{|c|c|c|c|}
\hline Themes & Hours & Directions & $\begin{array}{l}\text { Links to } \\
\text { materials* }\end{array}$ \\
\hline $\begin{array}{ll}\text { Introduction } & \text { to } \\
\text { Robotics } & \end{array}$ & 1 & TM, MD & {$[2]$} \\
\hline $\begin{array}{ll}\begin{array}{l}\text { Learning } \\
\text { overview }\end{array} & \text { robots } \\
\end{array}$ & 1 & TM, MD & [2-4] \\
\hline $\begin{array}{l}\text { Basic principles of } \\
\text { electronics (capacitor, } \\
\text { inductor, } \\
\text { potentiometer) }\end{array}$ & 1 & $\begin{array}{l}\text { TM, MD, } \\
\text { PD }\end{array}$ & [2] \\
\hline $\begin{array}{l}\text { Printed circuit board. } \\
\text { Electronics } \\
\text { manufacturing }\end{array}$ & 1 & $\begin{array}{l}\text { TM, MD, } \\
\text { PD }\end{array}$ & [2-3] \\
\hline $\begin{array}{l}\text { Different approaches to } \\
\text { the production of } \\
\text { printed circuit boards }\end{array}$ & 1 & $\begin{array}{l}\text { TM, MD, } \\
\text { PD }\end{array}$ & [8] \\
\hline $\begin{array}{l}\text { Robotics constructor } \\
\text { LEGO }\end{array}$ & 1 & TM, MD & [8] \\
\hline $\begin{array}{l}\text { Robotic constructors } \\
\text { Fischertechnik }\end{array}$ & 1 & TM, MD & [4-6] \\
\hline $\begin{array}{l}\text { Robotics constructors } \\
\text { Fable Spin and Fable } \\
\text { Joint from Shape } \\
\text { Robotics }\end{array}$ & 1 & TM, MD & [6] \\
\hline $\begin{array}{l}\text { Robotics constructors } \\
\text { VEX }\end{array}$ & 1 & $\mathrm{TM}, \mathrm{MD}$ & [7] \\
\hline $\begin{array}{ll}\text { Robotic } & \text { platform } \\
\text { Micro: bit } & \\
\end{array}$ & 1 & TM, MD & [7-9] \\
\hline $\begin{array}{ll}\text { Robotic } & \text { platform } \\
\text { Arduino } & \\
\end{array}$ & 1 & $\mathrm{TM}, \mathrm{MD}$ & [3-8] \\
\hline $\begin{array}{ll}\text { Robotic } & \text { Platform } \\
\text { Raspberry Pi } & \\
\end{array}$ & 1 & TM, MD & [11-12] \\
\hline $\begin{array}{l}\text { Modeling 3D elements } \\
\text { for a robot }\end{array}$ & 1 & TM, MD & [12-14] \\
\hline $\begin{array}{l}\text { 3D printer setting up } \\
\text { features }\end{array}$ & 1 & $\begin{array}{l}\text { TM, MD, } \\
\text { PD }\end{array}$ & [12-14] \\
\hline Total & 15 & & \\
\hline
\end{tabular}

* this column contains references to the literature that best covers the material on the topic.

Thus, within the framework of theoretical studies, we consider the most popular robotic constructors and platforms, discussing with students how a circle work can be organized or in which school classes robotic constructors can be used, which educational disciplines can help students in mastering robotics. By offering students the most complete overview, we form their horizons, which will allow them, in turn, to form the competencies of their future students within the framework of practice and further professional activity.

As part of discipline labs, students complete assignments in Tinkercad and EasyEDA. The main idea of planning laboratory work is to familiarize students with connecting the most popular sensors and elements of robotic systems using the example of working with the Arduino Uno microcontroller. Acquaintance with EasyEDA, and the design of 3D models, the ability to work with projects. Thus, students get a complete understanding of the technological cycle of the production of robotic structures.
An approximate list of themes [3], [7-10]:

Laboratory work No. 1 Flashing LED

Laboratory work No.2 Connecting the button

Laboratory work No.3 Connecting the potentiometer

Laboratory work No. 4 Servo control

Laboratory work No. 5 Three-color LED

Laboratory work No. 6 Piezoelectric element connection

Laboratory work No. 7 Connecting a photoresistor

Laboratory work No. 8 Connecting the motion sensor (PIR).

Laboratory work No. 9 Connection of temperature and humidity sensor DHT11 and DHT22

Laboratory work No. 10 Connecting a matrix keyboard and interesting schemes

Laboratory work No. 11 Connecting the DS3231 real-time clock module

Laboratory work No. 12 Designing a simple printed circuit board in EasyEDA.

Laboratory work No. 13 We plant a printed circuit board in EasyEDA.

Laboratory work No. 14 Creating a 3D model for printing

Laboratory work No. 15 Tracing and preparation for $3 \mathrm{D}$ printing

As part of students' independent work, it is advisable to consider ready-made projects of robotic systems [8], analyzing their effectiveness and forming topics for students' project activities within the framework of circle activities.

\section{RESULTS AND METHODS}

Competencies formed within the course.

Communicative competencies [15]:

- ability to team-working, the distribution of roles, understanding the role of each of the team members;

- ability to choose appropriate models of speech behavior depending on the situation, as well as to build communication in accordance with linguistic and ethical norms;

- ability to competently ask questions to other participants of the educational project;

- ability to competently, as well as to fully answer questions, to defend their positions in a reasoned manner; 
- ability to analyze incoming information, formulate your own opinion based on the understanding of various experiences, ideas and ideas;

- ability to self-control and self-organization;

- ability to present the material in a form understandable to others.

Making decisions competencies:

- ability to formulate a problem and find ways to solve it;

- search for the most effective ways to solve problems;

- independent formation of algorithms for solving problems;

Educational and cognitive competencies:

- ability to search, analyze and apply new knowledge to solve problems;

- using the acquired knowledge of programming in practice;

- skills in designing smart devices using the Arduino microcontroller.

Project competence:

- knowledge of the basics of project activities;

- ability to formulate and plan the work of students in a project group;

- understanding the educational needs of a different age group of students planning the work of the project team;

- ability to correctly coordinate the work of students in the framework of project activities;

- ability to identify and control the intermediate and final results of the educational project.

As part of the independent work, students were offered various projects implemented on the basis of Arduino microcontrollers. The most interesting, in our opinion were "Smart greenhouse", "Automatic feeder", "Multi-channel automatic watering by your own hands on Arduino", "Piggy bank with coin counter" [8], "CNC by your own hands on Arduino". The study of readymade projects allows you to show creativity in the work of students and activate the acquired knowledge.

As a controlling moment in mastering the basics of working with Arduino Uno, a kind of "dictation" was offered - students were offered a video on assembling the robot, the task was so that they could build a diagram of this robot and write a program for its work in Tinkercad.

\section{CONCLUSION}

Practice has shown that, despite the unfavorable conditions of classes, students have fully mastered the course material. Some of them expressed interest in further independent study of robotic systems for automating some greenhouse farming processes on the infield. This approach will make it possible to arouse cognitive interest among students, which in turn can lead to the organization of their circle work at school on project activities and further development of robotics.

Despite online learning, the information environments proposed in the article allow students to share schemes and projects with each other, as well as work together on a project. This approach will allow students to get the most complete picture of the proposed subject, expand their horizons about robotic constructors and platforms, which will allow them to organize club activities at school even without additional technical equipment (robotic constructors or the purchase of microcontrollers and other components).

\section{REFERENCES}

[1] Message of the First President of the Republic of Kazakhstan N. Nazarbayev to the people of Kazakhstan dated January 31, 2017 "The third modernization of Kazakhstan: global competitiveness", 2017. https://www.akorda.kz/ru/addresses/addresses_of_ president/poslanie-prezidenta-respubliki-kazahstannnazarbaeva-narodu-kazahstana-31-yanvarya2017-g.

[2] Sell, Raivo \& Altin, Heilo, Creating and Implementing Robotics For Schools. August 2016. Publisher: University of Tartu. Project: Erasmus+ Robotics for Schools, 2018. http://creativecommons.Org/licenses/by-nc-sa/3.0/.

[3] S. Eun Jung, E. Won, Systematic Review of Research Trends in Robotics Education for Young Children Sustainability 10(4) (2018) pp. 905. DOI: https://doi.org/10.3390/su10040905.

[4] S. Anwar, N. A. Bascou, M. Menekse, A. A Kardgar, Systematic Review of Studies on Educational Robotics. Journal of Pre-College Engineering Education Research, 9(2) (2019) pp. 19-42. http://docs.lib.purdue.edu/jpeer.

[5] N. A. Bascou, M. Menekse, A. A. Kardgar, Systematic Review of Studies on Educational Robotics. Journal of Pre-College Engineering Education Research (J-PEER), 9(2(2)) (2019). DOI: https://doi.org/10.7771/2157-9288.1223. 
[6] Universarium. Course "Introduction to Robotics", 2020.

https://www.youtube.com/watch?V=rudf6brysom.

[7] J. Beiktal, Building robots on Arduino. First steps, M.: Laboratory of knowledge, 2016, pp. 323.

[8] Stepic Course "Lego Construction and the Basics of Robotics", 2019. https://stepik.org/course/86400/promo.

[9] Stepic course "Robotics: The Basics of Lego EV3 Programming", https://stepik.org/course/65866/promo.

[10] Easytech educational YouTube channel, 2021. https://www.youtube.com/channel/uczrmftmr24k41 xqtjrnfaha.

[11] Course coursera "Building robots and other devices on Arduino. From traffic lights to 3D printers ", 2021. https://www.coursera.org/learn/robotyarduino/home/welcome.

[12] Learning site «Alexgyver Technologies», 2021. https://alexgyver.ru/.

[13] Youtube channel «Sergey Irbis», 2021. https://www.youtube.com/channel/UC4HMPEiKZ o0-kocnyhpvnua.

[14] W. Brian, Evans Arduino programmer's notebook, 2017. http://creativecommons.Org/licenses/by-nc$\mathrm{sa} / 3.0 /$.

[15] A. A. Zholdasbekov, M. Zh. Aymenov, Z. E. Shagataeva, N. A. Esimkhanova, J. D. Dzhartybaeva, N. S. Kolyeva, Formation of entrepreneurial competence in students majoring in pedagogy, Revista ESPACIOS. 40(31) (2019). 